\title{
Research on the Professional Ability Improvement Model of Engineering and Technical Personnel
}

\author{
Thura Nga \\ University of Transport Technology
}

\begin{abstract}
The process of international integration in science and technology of Vietnam has begun to be linked with the practical requirements of branches and localities, initially serving effectively for economic development tasks and the society of the country. However, human resources in science and technology in Vietnam are currently not sufficiently qualified to participate effectively in international and regional science and technology activities. Therefore, in order to raise and develop the level of science and technology capabilities of human resources for economic integration of Viet Nam into Asean, the authors aim to analyze factors influencing the capabilities of engineering technologists for Asean integration. For doing this, a total of two companies in Vietnam with 250 employees were surveyed and questioned during the last two years. The questionnaires were distributed to all the participants to collect data to answer the research questions. Structural equation modeling (SEM) was used to analyze and evaluate the factors (professional knowledge, foreign language proficiency, work management, labor environment, company policies, conditions for research and invention) that affect the capability of engineering technologist working in the companies. From identifying the factor that has the most subtantial influence on the capabilities of engineering technologists for Asean integration, the author suggests a training program for Engineering Technologist from the results of the study.
\end{abstract}

Keywords: ASEAN integration, competencies, capabilities, Vietnam, influence

\section{Introduction}

Impressive growth of Vietnam's trade volume in the period has been in questions among authors. There are number of studies, such as Jenkins (2004), Schmidt (2004), Pincus (2009) concentrating on examining the stable growth of Vietnam's trade performance in the world economic integration. However, a more fundamental issue for the trade growth that has been raised recently is which factors drive Vietnam's trade flows within the global economic integration process. Le et al. (1996) asserted that trade volume between Vietnam and Asia Pacific countries in early stage of trade liberalization was due to economic sizes, economic development levels and geographical distance. Gates (1998) investigating the effects of ASEAN Free Trade Area on Vietnam's trade pattern concluded the major determinants of bilateral trade flows between Vietnam and ASEAN members as: close distance between ASEAN members, lower transport costs, and good information on markets and trade policies.

The ASEAN Economic Community (AEC), established by the end of 2015, is considered a turning point marking the overall integration of Southeast Asian economies including Vietnam. The AEC will merge the economies of the 10 member states into one mass of trade and investment, creating a common market of a region with a population of 600 million and annual GDP of $\$ 2.5$ trillion. Accordingly, besides the flow of goods, services, capital, labor and capital, the free movement between ASEAN countries is a source of skilled labor. A labor market in general and a highly skilled labor market segment, skilled labor will soon be formed in the AEC. Vietnam is a member of ASEAN, so labor mobility between member countries including Vietnam is inevitable and also an opportunity for integration and competition in the labor market segment.

An engineer who wants to move between countries in the
ASEAN bloc needs to register with the ASEAN Professional Standards Engineering Coordinating Committee (ACPECC). Active access and registration with ACPECC will help engineers capture more job opportunities in 10 Southeast Asian countries. However, engineers must meet some requirements such as a professional engineer or practitioner who fully meets the standards of competence and practical experiences; completing a technical training program that is recognized and accepted; being qualified for independent practice; achieving at least 7 years of practical experiences since graduation; having at least 2 years of responsibility in important technical jobs; maintaining Continuous Professional Development (CPD); complying with ethics and professional code of conduct; keeping records for the purpose of monitoring each other.

However, human resources in science and technology in Vietnam are currently not sufficiently qualified to participate effectively in international and regional science and technology activities. The contribution of science and technology to international and regional scientific and technological activities remains low. The scientific research and technological development institutions, universities are not able to promote the expansion of international integration activities due to the lack of synchronous facilities and technical environment, the lack of professionalism, leading researchers, and technical staff. Most of the international cooperation in science and technology in recent years has only been implemented in the framework of bilateral or multilateral cooperation agreements. This leads to dependence on partners and unequal obligations and interests of each party. The enforcement of intellectual property law has not been effective, although the system of legal documents on intellectual property has met the adequacy and in accordance with international commitments that Vietnam is a member. Besides, the awareness of leaders at all levels and the whole society on this issue is limited. Technology transfer activities in key enterprises are only at the level of receiving through direct investment projects or 
foreign aids, without investment in research, ownership and technological innovation. Businesses often lack scientific and technological information at home and abroad. The link between scientific research and technological development and science and technology human resources training as well as integration needs of Vietnamese enterprises is limited.

To meet the requirements of professional engineer in the ASEAN countries and to successfully integrate in to ASEAN Economic Community, Vietnam needs high skills and competencies of engineering technologists that means high capabilities of technology. At present, the levels of capabilities of Vietnamese engineering technologists have not investigated to know the level. This study, therefore, is expected to investigate the factors influencing competencies and capabilities of Vietnamese technologists and engineer so as to suggest solutions to improve their capabilities. Many companies under investigation are from different industries such as automobile, mechanic, electric, textile, chemistry, construction industry for evaluating factors influencing competencies and capabilities of engineering technologies for Asean integration

Moreover, in the context of Vietnam in the development process in general and in transportation development in particular, it is vital to have engineering technologists who are qualified and skilled enough to promote the process. In the meanwhile, it is realized that this is a weak area that needs improvement. Realizing the importance of this section for the economic development of Vietnam, the authors would like to have a comprehensive investigation into factors influencing capabilities and competencies of Vietnamese engineering technologists in the process of integration in the ASEAN region, aiming to establish the bases for an enhancement program.

In this paper, the main objective is to analyze and evaluate the factors influencing competencies and capabilities of Vietnamese engineering technologies for Asian integration. For doing this, a total of two companies in Vietnam with 250 employees were surveyed and questioned during two years. The questionnaires were distributed to all the participants to collect data to answer the research questions. Structural equation modeling (SEM) was used to test the influential level of factors (professional knowledge, creative thinking and initiatives, foreign language proficiency, work management, attitudes and discipline, college curriculum, Labor environment, company policies, conditions for research and invention, and Personal factors) that affect the capability of engineering technologist working in the companies.

\section{Research Paradigm and Framework}

\section{Research Paradigm}

Depending on research problems and objectives as well as theoretical foundations for analyzing competencies and capabilities of engineering technologists in selected companies in Vietnam, the research paradigm is based on experimental perspective to carry out. It means that the authors used the quantitative method with questionnaire survey and observation of real issues to analyze and evaluate factors influencing capabilities of engineering technologies for Asean integration. Therefore, the authors develop research paradigm to implement this study as in Figure 1.

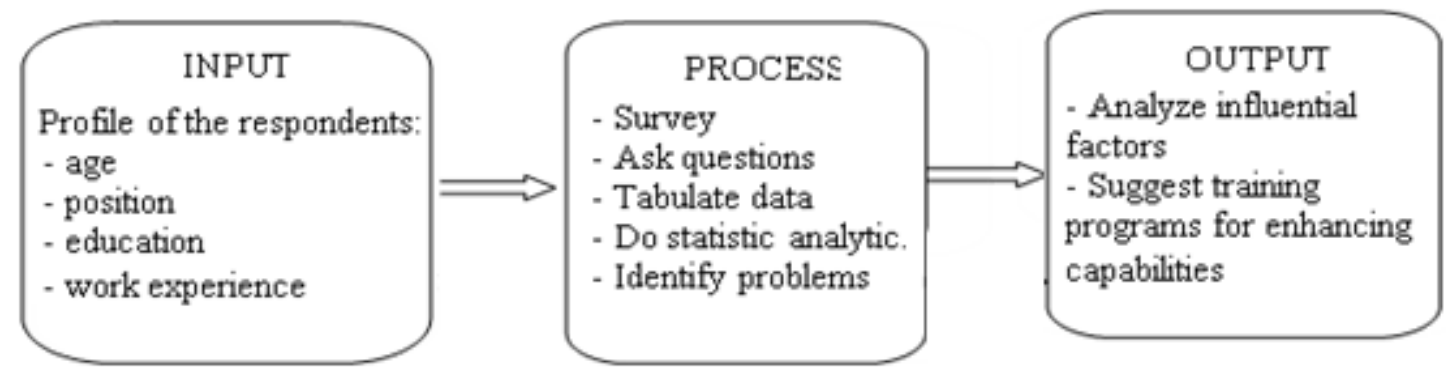

Figure 1: Research paradigm

In order to implement this study with objectives, the author need input data related to respondents' background such as age, position, education and work experiences. From the basic input data, the author can analyze the factors influencing capabilities of engineering technologiests related to objectives of the study.

In order to implement this study, the author needs clear processes to do step by step as in Figure 1 including conducting survey, asking questions, tabulating data, doing statistics analysis, and finding problems.

For output of this study, the authors hope that the study can analyze and evaluate factors influencing capabilities and engineering technologists, therefore suggest some proposal action and training programs to improve competencies and capabilities of engineering technologists in Vietnam for Asean integration.

\section{Research Framework}

There are many factors influencing the capabilities of engineering technologists such as individual factors and external factors. For individual factors the study addressed age, education attainment, work experiences, and position (Engineers Ireland, 2005; Lân, 2012; Land, 2012). Besides, some external conditions and environment are also mentioned such as curriculum, labor environment in Vietnam, the treatment Policy of company, and conditions to research and invention. Based on the previous researches on the capability of Engineering Technologist and the gaps between ASEAN requirements for engineering technologists and the practice in Vietnam, the author develops conceptual 
framework (see Figure 2) based on some assumptions as follows:

The authors assumes that competencies does not significantly influence on the Capability of Engineering Technologist.

The detail of item scale of Competencies for this assumption is based on the previous studies of (Engineers Ireland, 2005; Lân, 2012; Land, 2012; Sew, 2000; United Nations, 2009). Some previous researchers mentioned professional knowledge related to staff's qualification to evaluate curriculum (Lan, 2012). Other previous authors addressed personal competencies through soft skills and foreign language proficiency. Sew (2000) also did research related to attitudes and discipline in work such as continuous improvement, creative thinking, in time working, etc. Otherwise, they are also based on the author's self development after reviewing the literature of this topic. So the variable of competencies in this study is measured with 5 items of professional knowledge, creative thinking, personal effectiveness, work management, and attitude and discipline in work. The five items in some extent may have influence on the capabilities of engineering technologists.

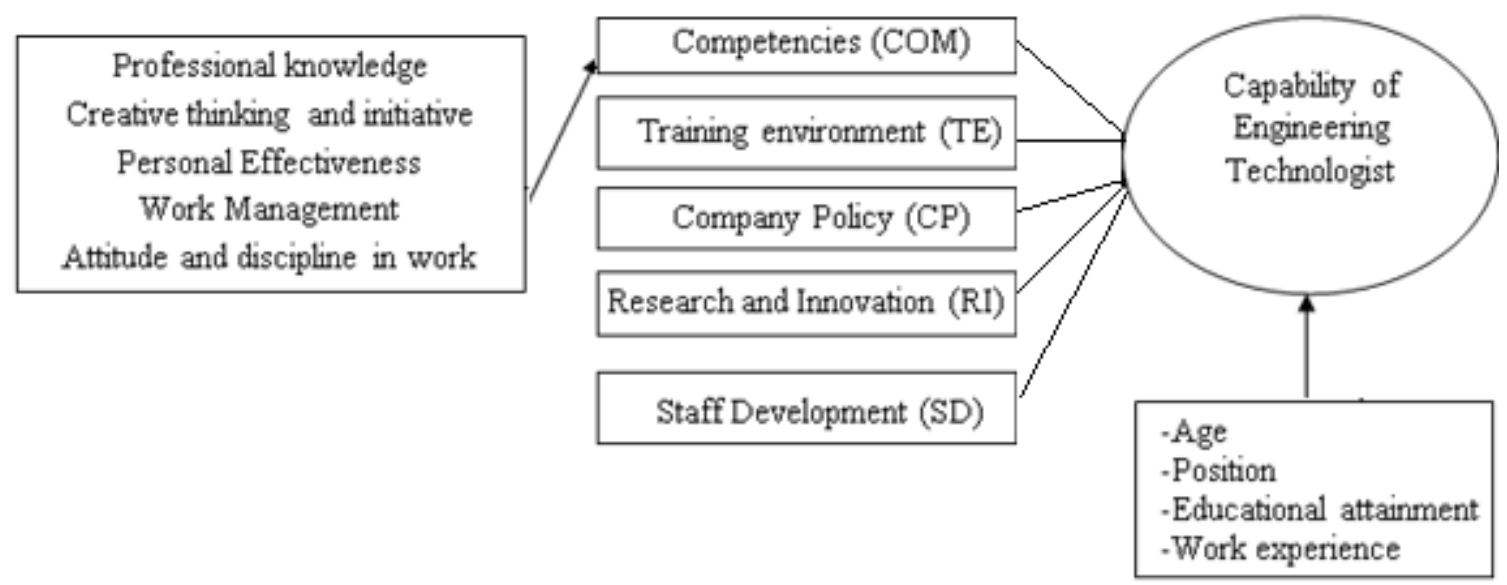

Figure 2.2: Conceptual Framework

The author assumes that training environment (TE) in Vietnam does not significantly influence on the Capability of Engineering Technologist

The detail of item scale of training environment in Vietnam for this assumption is based on the previous studies of (Engineers Ireland, 2005; Lân, 2012; Land, 2012; Sew, 2000; United Nations, 2009). According to Lan (2012) and some authors in Vietnam, training technology engineer in Vietnam should meet the market demand, especially for companies recruiting and using these engineer and technology labors. For example, the training program of IT, it should help labors easy to master the advanced technology and develop labors' career. Otherwise, they are also based on the author's self - development after reviewing the literature of this topic. Labor environment in Vietnam (LAB) my include the training program is suitable to the requirements of the job of the technology engineer when integrating into ASEAN, the training program helps you easy to master the advanced technology, the training gives you many opportunities to develop your future career, the training program gives you the skills you need to do the job, the training program gives you with ratio between theory and practice is reasonable.

The author assumes that company policy does not significantly influence on the Capability of Engineering Technologist

The detail of item scale of company policy for this assumption is based on the previous studies of (Engineers Ireland, 2005; Lân, 2012; Land, 2012; Sew, 2000; United Nations, 2009). Treatment policy from previous authors include requirement of recruiting technologists and engineers, the competition among technology engineers in Asean countries. Otherwise, they are also based on the author's self - development after reviewing the literature of this topic. The treatment policy of company $(\mathrm{CP})$ has 4 main items of demand for high quality engineering technology workers is increasing, requirement of recruiting technology engineers is becoming more strict when ASEAN integration, the competition with the technology engineers of ASEAN countries is increasingly fierce, the working environment creates opportunities for employees to develop and innovate.

The author assumes that research and invention (RI) does not significantly influence on the Capability of Engineering Technologist

The detail of item scale of conditions to research and invention for this hypothesis is based on the previous studies of (Engineers Ireland, 2005; Lân, 2012; Land, 2012; Sew, 2000; United Nations, 2009). For this variable, Sew (2000) also mentioned policies to support and advanced training for technology engineers for example paying training fees for short and advanced courses. The higher income also discussed by some authors because it motivates the effort and invention capacity of technology engineers. In many researches, the payment should be equal or in accordance with the capacity of the engineers trained. Otherwise, they are also based on the author's self - development after reviewing the literature of this topic. So Conditions to research and invention (RI) may compose of the policies for research and invention are very good, big funds for investment in patent research activities, highly paid patents by the business, The full facilities to research and invention. 
The author assumes that factors belongs to staff development does not significantly influence on the Capability of Engineering Technologist

The detail of item scale of factors belonging to staff development for this assumption is based on the previous studies of (Engineers Ireland, 2005; Lân, 2012; Land, 2012; Sew, 2000; United Nations, 2009). Related to factors belonging to staff development, some authors mentioned the awareness of opportunities for themselves when ASEAN integration, the seriousness in preparing for ASEAN integration, good health to withstand with pressures of the work. They are really important for engineer and technologists. Otherwise, they are also based on the author's self - development after reviewing the literature of this topic. Factors belonging to staff development (SD) may include awareness of engineers related to opportunities for themselves when ASEAN integration, seriousness of engineers in preparing for ASEAN integration, Be in good health to withstand the pressure of work, The clear goal of capacity building, and engineers' awareness of opportunities for themselves when ASEAN integration

The author assumes that there is a statistically significant correlation between ages and Capability of Engineering Technologist

The detail of item scale of professional knowledge for this assumption is based on the previous studies of (Engineers Ireland, 2005; Lân, 2012; Land, 2012; Sew, 2000; United Nations, 2009). For professional knowledge, some observed items are mentioned in previous research including ability to solve the technical problem, capability of monitoring issues in performance process, ability to perform detailed tasks, and ability to work with information data (Lân, 2012; Land, 2012) . Otherwise, they are also based on the author's self development after reviewing the literature of this topic. For professional knowledge (PW), it may include eight items of professional knowledge to ensure the performance job, effective usage of knowledge, necessary job skills and knowledge, ability to judge the work within the function of unit, Ability to solve the technical problem within the function of unit, capability of monitoring issues in performance process, ability to perform detailed tasks, and ability to work with information, data

The author assumes that there is a statistically significant correlation between Field of activity and Capability of Engineering Technologist

The detail of item scale of creative thinking for this assumption is based on the previous studies of (Engineers Ireland, 2005; Lân, 2012; Land, 2012; Sew, 2000; United Nations, 2009). For creative thinking, some observed items are developed based on the previous research such as changing the work methods, taking initiative to meet job challenges, creating links with colleagues, giving more options when solving problems, engaging in innovation and risk - taking (D. Milan, 2016; Germain \& Williams, 2015; $\mathrm{Na}$ ) . Otherwise, they are also based on the author's self development after reviewing the literature of this topic. Therefore, it is composed of the initiative to meet jobs challenges, ability to undertake new tasks, appropriate method for each job, changing working methods, creating links with colleagues to promote initiatives, giving more options when solving a problem, expanding creativity and innovation, initiating job enrichment and redesign, engaging in innovation and risk - taking, and expanding knowledge regarding relevant issues

The author assumes that there is a statistically significant correlation between position and Capability of Engineering Technologist

The detail of item scale of Personal effectiveness for this assumption is based on the previous studies of (Engineers Ireland, 2005; Lân, 2012; Land, 2012; Sew, 2000; United Nations, 2009). For the variable of personal effectiveness can be described through some observed items including such as ability to use foreign languages in work, skills to draft the text in foreign language, and the ability to use information technology (D. Milan, 2016; Engineering Council, 2017) . Otherwise, they are also based on the author's self - development after reviewing the literature of this topic. Therefore, variable of personal effectiveness (PE) is developed with 3 main items of ability to use foreign languages in work, to have the skills to draft the text in a foreign language, and to use information technology.

The author assumes that there is a statistically significant correlation between educational attainment and Capability of Engineering Technologist

The detail of item scale of Attitude and Discipline in Work for this assumption is based on the previous studies of (Engineers Ireland, 2005; Land, 2012; Lân, 2012; Sew, 2000; United Nations, 2009). For the variable, the observed items can be seen through having good ethical qualities, compliance with labor disciplines, understanding society and law. Otherwise, they are also based on the author's self development after reviewing the literature of this topic. Therefore, the variable of attitude and discipline in Work (AD) is developed with 5 main items of having good ethical qualities, having good awareness of organization discipline, responsible for themselves and work, compliance with labor discipline, understanding of society and law; and having good health.

The author assumes that there is a statistically significant correlation between work management and Capability of Engineering Technologist

The detail of item scale of Work Management for this assumption is based on the previous studies of (Engineers Ireland, 2005; Land, 2012; Lân, 2012; Sew, 2000; United Nations, 2009). The variable of work management includes 10 manifest variables including some ones extracted from previous research such as completion on time, working in team, clear plan with assigned tasks, ... (Varona, 2013; Milan, 2016; Sew, 2000) . Otherwise, they are also based on the author's self - development after reviewing the literature of this topic. So this variable can be developed with 10 items of defining your COMrent capacity and actively learn to improve knowledge, carrying out the work to manage according to plan, on time working, ability to work as a team and work independently, contributing solutions to 
performance good job, always creation in the job, assigning tasks scientifically for myself and colleagues, taking the initiative in assigned tasks with clear plan, ability to adaptability and flexibility in the work, and excellent work performance.

\section{Research Methodology}

Research design is the modeling of research ideas, including the preparation of conditions for collection and analysis of data to achieve research objectives. To achieve the research objectives set out, the research process is carried out mainly through quantitative studies.

\section{Population and sample size}

The method of determining the sample size in the research is consulted from the method of determining the sample size of Hair et al. (2006); meaning that the sample size was determined based on: minimum and variable quantities included in the analysis of the model, where the minimum is usually 50 (Hair et al., 2006). Hair et al. (1998) suggested that if the sample size was about 100, the Factor Loading criterion should be greater than 0.5 and also the author has proposed a 5: 1 ratio for sample size selection versus the number of parameters in the multivariate analysis. The researcher's model identified 31 variables, using the Likert scale. The original sample size was $58 * 5=290$. Excluding ineligible questionnaires, the researcher decided to choose the number of the questionnaire is 400 .

\section{Statistical techniques for modeling}

Questionnaires after collection will be checked to avoid errors and inconsistent information. After that, all collected questionnaires will be encoded and entered into SPSS 20.0 and AMOS 20 software to filter for subsequent studies.

\section{Scale reliability testing}

Cronbach's Alpha reliability index only indicates whether the measurements are linked or not, but the index does not indicate which observation variable should be discarded or retained. Then, the calculation of the correlation coefficient between variables would help to eliminate the observation variables which did not contribute much to the description of the concepts (Hoang Trong and Nguyen Mong Ngoc, 2005).

\section{Exploratory factor analysis}

An exploratory factor analysis (EFA) is a quantitative analysis method used to shorten the set of interdependent observation variables into a meaningful set of variables (Hair et al., 2009). In the study, Principal Axis Factoring method was used. According to Hair et al. (1998), factor loading is an indicator to ensure a realistic level of exploratory factor analysis. Bartlett's test of sphericity tests the hypothesis that your correlation matrix is an identity matrix, which would indicate that your variables are unrelated and therefore unsuitable for structure detection. The significance level less than 0.05 in the Bartlett's test indicate that a factor analysis may be useful with the research data.

\section{Confirmatory Factor Analysis (CFA)}

Confirmatory factor analysis (CFA) is a multivariate statistical procedure that is used to test how well the measured variables represent the number of constructs. In confirmatory factor analysis, researchers can specify the number of factors required in the data and which measured variable is related to which latent variable. Confirmatory factor analysis (CFA) is a tool that is used to confirm or reject the measurement theory. CFA is implemented on the measurement model to exclude variables with low factor loading. CFA can be performed for each sub - model prior to testing for a whole model.

\section{Structural equation modeling (SEM)}

In order to find out the impact level of factors that affect the capabality of engineering technologist, hypothesis testing and SEM modeling were used with the more advantageous than traditional methods (such as multivariate regression) due to the measurement error. The SEM model was an extension of the general linear model (GLM) that allowed the researcher to test a set of regression equations at the same time. The SEM was used to indicate the relationships between latent variables. Specifically, in this study, the author used the SEM model to test: the factors affecting to capabality of engineering technologist and the factors constitutes to capabality of engineering technologist.

\section{Data Used}

In this study, data was collected in the North of Vietnam with many companies related to different fields as the author mentioned. For automobile industry, the survey was carried out at companies in the North of Vietnam for understanding the competencies and preparedness. The population composed of workforce doing in their jobs in different companies with various fields, include Engineering Technologist and managers who are working in these companies. The authors sent 400 questionnaires by email and through direct meetings with these companies. The researcher set 5\% allowance for sampling error; the sample size is 350 respondents and sampled using the Simple random sampling technique. Sample respondents include 350 personnel who are working at different companies with various fields, in which: 51 respondents are managers and 258 respondents are Engineering Technologists, and 41 respondents are employees.

\section{Results and Discussion}

To analyze factors influencing the capabilities of engineering technologiests for Asean integration, we built and developed a research framework in the part of research paradigm and framework. In order to establish significant relationship between factors on capabilities of engineering technologists, the authors run SPSS and SEM to test measurement model and structural model.

\section{The results of measurement model}

The research model of the study has the dependent variable of Capabilities of Engineering Technologist (CET). It is affected by five independent variables of competencies of engineering technologist (COM), training environment (TE), Company Policies (CP), Research and Innovation (RI), and Staff Development (SD). For the variable of competencies (COM), it includes (1) Professional knowledge; (2) Creative thinking and initiative; (3) Personal effectiveness competencies and Foreign language proficiency; (4) Work 
Management; (5) Attitude and discipline in work. Four independent variables of training environment (TE), Company Policies (CP), Research and Innovation (RI), and Staff Development (SD) measure the practices of engineering technologists.

For measurement model, the Cronbach's Alpha reliability testing is a scale - measuring tool that uses to eliminate unsatisfactory variables. Variables with Corrected Item Total Correlation less than 0.30 will be rejected. The Cronbach's Alpha coefficient of 0.6 or more can be useable in the case of new research (Nunnally, 1994). Cronbach's Alpha range from 0.7 to 0.8 is usually available, scale from 0.8 to 1.0 is a good scale.

The results shows the test reliability of the scale after the variables: CI9 - Expanding knowledge regarding relevant issues; CI10 - Engaging in innovation and risk - taking; WM2 - To carry out the work to manage according to plan; WM5 - Contribute solutions to performance good job; WM8 - Always take the initiative in assigned tasks with clear plan; WM10 - The rating in performance evaluation showed excellent work performance; LAB4 - The training program gives you the skills you need to do the job, LAB5 - The training program gives you with ratio between theory and practice is reasonable were excluded in the EFA step Because of the coefficient of correlation the total variables are: $0.285 ; 0.200 ; 0.256 ; 0.215 ; 0.235 ; 0.311 ; 0.124 ; 0.104$ respectively, less than 0.3 (Appendix 3). After moving these varaibles, the result shows that the scales both have a reasonalble strong Cronbach's Alpha coefficient and the Corrected item - Total correlation of items are all more than 0.3 . Thus, the proposed items measure the same concepts and the scales are realiable for using.

Examples of Reliability Statistics of Staff Development

\begin{tabular}{|c|c|c|c|c|}
\hline \multicolumn{3}{|c|}{ Cronbach's Alpha } & \multicolumn{2}{c|}{ N of Items } \\
\hline \multicolumn{3}{|c|}{0.847} & \multicolumn{2}{c|}{5} \\
\hline No. & $\begin{array}{c}\text { Scale Mean if } \\
\text { Item Deleted }\end{array}$ & $\begin{array}{c}\text { Scale Variance if } \\
\text { Item Deleted }\end{array}$ & $\begin{array}{c}\text { Corrected Item - } \\
\text { Total Correlation }\end{array}$ & $\begin{array}{c}\text { Cronbach's Alpha } \\
\text { if Item Deleted }\end{array}$ \\
\hline ED1 & 14.99 & 6.620 & .714 & .801 \\
\hline ED2 & 15.03 & 6.421 & .598 & .833 \\
\hline ED3 & 15.01 & 6.614 & .680 & .809 \\
\hline ED4 & 14.99 & 6.784 & .588 & .833 \\
\hline ED5 & 14.99 & 6.322 & .711 & .800 \\
\hline
\end{tabular}

After analyzing cronbach's alpha, the author excluded 8 unsatisfactory variables, then continue to analyze EFA. The EFA uses the Principal Axis Factoring extraction method (Gerbing \& erson, 1988) with a load factor $\geq 0.5$ (Hair \& associates, 1998) for both the 50 independent variables. Bartlett's test examines the hypothesis of the correlation between observed variables. The results showed that the $\mathrm{KMO}=0.845(0.5<=\mathrm{KMO}<=1) ;$ and Bartlett's Test statistic $=9507.635 \mathrm{Sig}=0.00<0.05$ (Appendix 4.1), it means that the application of exploratory factor analysis in the study is appropriate. Moreover, factors have the eigenvalue $>1$ which explains is greater than $50 \%$ $(64.241 \%)$, the observed variables are grouped exactly as the initial scale (appendix 4.2). Factor loadings are greater than 0.5 , ensuring the distinction between Loading Factors (greater than 0.3); and the variables retained exactly as the groups in the original scale (appendix 4.3). Thus, after the analysis of EFA, the model is not different from the proposed model; There are no new factor groups.

\begin{tabular}{|c|c|c|}
\hline \multicolumn{3}{|c|}{ Examples of EFA - KMO and Bartlett's Test } \\
\hline \multicolumn{2}{|c|}{$\begin{array}{l}\text { Kaiser - Meyer - Olkin Measure of Sampling } \\
\text { Adequacy. }\end{array}$} & 0.845 \\
\hline \multirow{3}{*}{$\begin{array}{l}\text { Bartlett's Test of } \\
\text { Sphericity }\end{array}$} & Approx. Chi - Square & 9507.635 \\
\hline & $\mathrm{df}$ & 1275 \\
\hline & Sig. & 0 \\
\hline
\end{tabular}

\begin{tabular}{|c|c|c|c|c|c|c|c|c|c|c|}
\hline \multicolumn{10}{|c|}{ Pattern Matrix $^{\mathbf{a}}$} \\
\hline & \multicolumn{10}{|c|}{ Factor } \\
\hline & 1 & 2 & 3 & 4 & 5 & 6 & 7 & 8 & 9 & 10 \\
\hline CI4 & 0.859 & & & & & & & & & \\
\hline CI7 & 0.794 & & & & & & & & & \\
\hline CI3 & 0.783 & & & & & & & & & \\
\hline CI2 & 0.763 & & & & & & & & & \\
\hline CI8 & 0.692 & & & & & & & & & \\
\hline
\end{tabular}

\begin{tabular}{|c|c|c|c|l|l|l|l|l|l|l|}
\hline CI6 & 0.657 & & & & & & & & \\
\hline C15 & 0.627 & & & & & & & & \\
\hline C1 & 0.538 & & & & & & & & & \\
\hline PW6 & & 0.809 & & & & & & & & \\
\hline PW2 & & 0.79 & & & & & & & & \\
\hline PW3 & & 0.734 & & & & & & & & \\
\hline PW4 & & 0.711 & & & & & & & & \\
\hline PW1 & & 0.71 & & & & & & & & \\
\hline PW5 & & 0.685 & & & & & & & & \\
\hline PW7 & & 0.656 & & & & & & & & \\
\hline PW8 & & 0.551 & & & & & & & & \\
\hline AD4 & & & 0.835 & & & & & & & \\
\hline AD2 & & & 0.83 & & & & & & & \\
\hline AD1 & & & 0.807 & & & & & & & \\
\hline AD3 & & & 0.773 & & & & & & & \\
\hline AD5 & & & 0.742 & & & & & & & \\
\hline WM7 & & & & 0.796 & & & & & & \\
\hline WM4 & & & & 0.793 & & & & & & \\
\hline WM1 & & & & 0.744 & & & & & & \\
\hline WM3 & & & & 0.638 & & & & & & \\
\hline WM9 & & & & 0.604 & & & & & & \\
\hline WM6 & & & & 0.589 & & & & & \\
\hline COM3 & & & & & 0.841 & & & & & \\
\hline COM2 & & & & & 0.813 & & & & & \\
\hline COM4 & & & & & 0.698 & & & & & \\
\hline COM1 & & & & & 0.696 & & & & & \\
\hline COM5 & & & & & 0.617 & & & & & \\
\hline TE5 & & & & & & 0.783 & & & & \\
\hline TE1 & & & & & & 0.768 & & & & \\
\hline TE3 & & & & & & 0.718 & & & & \\
\hline TE4 & & & & & & 0.694 & & & & \\
\hline TE2 & & & & & & 0.669 & & & & \\
\hline COMP3 & & & & & & & 0.824 & & & \\
\hline COMP2 & & & & & & & 0.811 & & & \\
\hline COMP1 & & & & & & & 0.655 & & & \\
\hline COMP4 & & & & & & & 0.639 & & & \\
\hline R11 & & & & & & & & 0.823 & & \\
\hline
\end{tabular}




\begin{tabular}{|c|l|l|l|l|l|l|l|l|l|}
\hline RI2 & & & & & & & & 0.781 & \\
\hline RI3 & & & & & & & & 0.749 & \\
\hline SD2 & & & & & & & & & 0.743 \\
\hline SD1 & & & & & & & & & 0.736 \\
\hline SD3 & & & & & & & & & 0.574 \\
\hline SD4 & & & & & & & & & 0.561 \\
\hline
\end{tabular}

Extraction Method: Principal Axis Factoring. Rotation Method: Promax with Kaiser Normalization.

The factors constituting to competencies of engineering technologist are: (1) Professional knowledge; (2) Creative thinking and initiative; (3) Personal effectiveness competencies and Foreign language proficiency; (4) Work Management; (5) Attitude and discipline in work.

The results of confirmatory factor analysis indicates that Chi - square $=860.310 ; \mathrm{df}=392(\mathrm{p}=0.000<0.05)$; Chi - square
$/ \mathrm{df}=2.195(\mathrm{df}<3) ; \mathrm{TLI}=0.906 ; \mathrm{CFI}=0.915(\mathrm{TLI}, \mathrm{CFI}>$ $0.9)$; GFI $=0.864>0.8$ and RMSEA $=0.059<0.08$. The result indicates that correlation coefficients are less than 1 , covariance tests and correlations between paired variables are statistically significant ( $\mathrm{p}$ - value $<0.05$, Appendix 6.1).

\section{The results of structural model and hypothesis}

The research used structural equation model (SEM) to assess relevance of the model and evaluate influential relationships in the research model. The results of Structural equation modeling analysis indicates that $\mathrm{Chi}$ - square $=2003.358 ; \mathrm{df}$ $=1197(\mathrm{p}=0.000<0.05) ;$ Chi - square $/ \mathrm{df}=1.674(\mathrm{df}<3)$; $\mathrm{TLI}=0.902 ; \mathrm{CFI}=0.908(\mathrm{TLI}, \mathrm{CFI}>0.9) ; \mathrm{GFI}=0.824>$ 0.8 and RMSEA $=0.044<0.08$. Therefore, it is possible to conclude that the model achieves compatibility with the data.

Table 4.24: Results of hypothesis test

\begin{tabular}{|c|c|c|c|c|c|c|c|c|}
\hline \multicolumn{2}{|c|}{ Relation } & Hypothesis & Estimate (standardized) & S. E. & C. R. & P & Result \\
\hline CET & $<---$ & COM & H1 & .355 & .051 & 4.760 & $* * *$ & Accepted \\
\hline CET & $<---$ & TE & H2 & .187 & .042 & 3.409 & $* * *$ & Accepted \\
\hline CET & $<---$ & CP & H3 & 206 & .038 & 3.104 & .002 & Accepted \\
\hline CET & $<---$ & RI & H4 & .234 & .039 & 2.868 & .004 & Accepted \\
\hline CET & $<---$ & SD & H5 & 265 & .037 & 3.819 & $* * *$ & Accepted \\
\hline
\end{tabular}

(Source: Processing data of the authors

The results showed that the elements: Competencies (COM); Training environment in Vietnam (TE); The Policy of company (CP); Conditions to research and innovation (RI); Factors belongs to staff development (SD) have a positive impact on Capability of Engineering Technologist, in which the strongest influence on the Capability of Engineering Technologist is COMriculum (coefficient is 0.355), followed by Conditions to research and invention (coefficient is 0.234), The treatment Policy of company (coefficient is 0.206), and finally training environment in Vietnam (coefficient is 0.187). Therefore, Hypotheses H1, H2, H3, H4, H5are accepted ( $\mathrm{p}$ - value <0.05).

The results showed that the elements: Competencies (COM); Training environment in Vietnam (TE); The Policy of company (CP); Conditions to research and innovation (RI); Factors belongs to staff development (SD) have a positive impact on Capability of Engineering Technologist, in which the strongest influence on the Capability of Engineering Technologist is Competencies (coefficient is 0.355), followed by Conditions to research and invention (coefficient is 0.234), The treatment Policy of company (coefficient is 0.206), and finally training environment in Vietnam (coefficient is 0.187). Therefore, Hypotheses H1, $\mathrm{H} 2, \mathrm{H} 3, \mathrm{H} 4$, H5are accepted (p - value <0.05).

To propose a training program for Engineering Technologists based from the model andlow - rated indicators

After analyzing the factors influencing capabilities of engineering technologiet, we know more clearly which factors have strong impact. Therefore, the objective of this study is to propose a training program to enhance the competencies and practices of engineering technologists for
Asean Integration, the authors suggest a framework of proposing.

To help accelerate the improvement of training systems and the mutual recognition of skills, the ILO has developed, in consultation with employers, governments and workers, the Regional Model Competency Standards (RMCS). These have been developed in identified. Priority areas and in a simplified format. Competency standards are a set of benchmarks that define the skills, knowledge and attributes people need to perform a work role. They are developed in consultation with industry, in order to ensure they reflect the needs of the workplace. Competency standards form the basis upon which training and assessment can be implemented to a standard that the industry recognizes and trusts. Competency standards are primarily used to develop and implement training, to assess the outcomes of training, and to assess the level of a person's existing skills and competencies.

The authors based on these standards and actual situation of evaluating competency and practices to propose training programs for enhancing the competencies and practices of engineering technologist and harmonizing the competencies assessment with the ASEAN Engineering requirements. The framework is developed based on the previous findings and actual situation of training engineering technologist in Vietnam. The author focused on some main industries to propose the training framework including automobile and mechanic engineering, electrical and electric engineering, and IT engineering because they are somewhat related. Most of contents of training programs that the author suggested are based on the training method of Profession - Oriented Higher Education - POHE 
The framework of training program for engineering technologies can be classified following industry and done

through the framework as follows.

Framework of Training Program for engineering technologists

\begin{tabular}{|c|c|c|c|}
\hline No. & $\begin{array}{c}\text { Requirements and } \\
\text { Standards }\end{array}$ & $\begin{array}{l}\text { Name and content of } \\
\text { training program }\end{array}$ & Skills and capabilities developed \\
\hline 1. & $\begin{array}{l}\text { A thorough knowledge of } \\
\text { the principles of } \\
\text { engineering, based on } \\
\text { mathematics, physics and } \\
\text { informatics, appropriate } \\
\text { to their discipline }\end{array}$ & $\begin{array}{l}\text { Training program of } \\
\text { mechanical engineering, } \\
\text { information technology, } \\
\text { electrical and electric } \\
\text { engineering, ... (within } \\
\text { initial years) - POHE }\end{array}$ & $\begin{array}{l}\text { - Communicate with professionals, leaders, users of mechanical } \\
\text { machinery and use English in communication } \\
\text { - Understanding the social and legal issues of the State } \\
\text { - Planning and solving professional problems independently or in } \\
\text { groups, demonstrating leadership competencies. }\end{array}$ \\
\hline 2. & $\begin{array}{l}\text { Establishes engineering } \\
\text { business/ organization } \\
\text { direction }\end{array}$ & $\begin{array}{c}\text { Career Direction and } \\
\text { Pathway }\end{array}$ & $\begin{array}{l}\text { - Develops engineering strategies } \\
\text { - Interprets strategic goals to integrate with engineering business } \\
\text { planning } \\
\text { - Seizes wealth creation opportunities for communities and business } \\
\text { - Produces environmental scan for engineering developments } \\
\text { - Identifies and assesses new technologies } \\
\text { - Monitors and contributes to market plans for engineering applications }\end{array}$ \\
\hline 3. & $\begin{array}{l}\text { Manages a multi - } \\
\text { disciplined team }\end{array}$ & $\begin{array}{l}\text { Team management and } \\
\text { Skill of Working in team }\end{array}$ & $\begin{array}{l}\text { - Leads communication across professional groups } \\
\text { - Develops and manages the performance of a diverse team } \\
\text { - Ensures documentation of outcomes are integrated across professions } \\
\text { - Provides leadership on ethical considerations across disciplines }\end{array}$ \\
\hline 4. & $\begin{array}{l}\text { The ability to develop and } \\
\text { use theoretical models } \\
\text { from which the behavior } \\
\text { of the physical world can } \\
\text { be predicted }\end{array}$ & $\begin{array}{l}\text { Training program of } \\
\text { mechanical engineering, } \\
\text { information technology, } \\
\text { electrical and electric } \\
\text { engineering, ... (within } \\
\text { final years) - POHE }\end{array}$ & $\begin{array}{l}\text { - Design of machinery and equipment to meet the market demand and } \\
\text { application of information technology in machine design. } \\
\text { - Repair, maintenance and operation of machinery and equipment. } \\
\text { Transfer of technical advances, technologies and new food machinery } \\
\text { and equipment into production. } \\
\text { - Detect problems, implement scientific research activities, and apply } \\
\text { information technology to handle research results in professional } \\
\text { fields. }\end{array}$ \\
\hline 5. & $\begin{array}{l}\text { A general knowledge of } \\
\text { good engineering practice } \\
\text { in their field of } \\
\text { engineering and the } \\
\text { properties, behavior, } \\
\text { fabrication and use of } \\
\text { materials, components } \\
\text { and software } \\
\end{array}$ & $\begin{array}{l}\text { Training program of } \\
\text { mechanical engineering, } \\
\text { information technology, } \\
\text { electrical and electric } \\
\text { engineering within } 4 \text { - } 5 \\
\text { years - POHE }\end{array}$ & $\begin{array}{l}\text { - Communicate with professionals, leaders, users of mechanical } \\
\text { machinery, IT, and EEE } \\
\text { - Understanding the social and legal issues of the State. } \\
\text { - Planning and solving professional problems independently or in } \\
\text { groups, demonstrating leadership. }\end{array}$ \\
\hline 6. & $\begin{array}{l}\text { Knowledge of the use of } \\
\text { technologies } \\
\text { relevant to their field of } \\
\text { specialization }\end{array}$ & $\begin{array}{l}\text { Training program of } \\
\text { mechanical engineering, } \\
\text { information technology, } \\
\text { electrical and electric } \\
\text { engineering within } 4 \text { - } 5 \\
\text { years - POHE }\end{array}$ & $\begin{array}{l}\text { - Design and manufacture of machinery and equipment to meet the } \\
\text { market demand and application of information technology in machine } \\
\text { design } \\
\text { - Repair, maintenance, operation machinery and equipment } \\
\text { - Transfer advanced technology, technology and new food machinery } \\
\text { into production. } \\
\text { - Detects problems, conducts scientific research activities, applies } \\
\text { informatics in processing research results in professional fields. }\end{array}$ \\
\hline
\end{tabular}

\section{Conclusions}

The driving aim of this study was to investigate the influences of factors on capabilities of engineering technologists of Vietnamese companies for Asean integration; and based on that to suggest training programmes to improve their competencies in their workplaces for Asean integration. ASEAN integration and internalization may help the developing countries in Asia to effectively exploit the scientific and technological achievements of the world, attract foreign resources and technology. This study has provided useful data to have a comprehensive picture of the capacities of engineering technologists in the ASEAN integration process and factors influencing the capabilities. It is expected that the findings of the study would contribute to the understanding of capacities of Vietnamese technology engineers. While more research needs to be conducted in this area, it is hoped that the suggestions and recommendations for improvement made in this study would make a modest contribution to the area of engineering technologist professional development.

\section{References}

[1] Akram, Q. F., Rime, D., \& Sarno, L. (2008). Arbitrage in the foreign exchange market: Turning on the microscope. Journal of International Economics, 76 (2), $237-253$.

[2] Axtell, M. J., Snyder, J. A., \& Bartel, D. P. (2007). Common functions for diverse small RNAs of land plants. The Plant Cell, 19 (6), 1750 - 1769.

[3] Beaver, G., \& Prince, C. (2002). Innovation, entrepreneurship and competitive advantage in the entrepreneurial venture. Journal of Small Business and Enterprise Development, 9 (1), 28 - 37.

[4] Baldwin, T. T., Ford, J. K., \& Blume, B. D. (2009). 
Transfer of training 1988-2008: an updated review and agenda for future research. International review of industrial and organizational psychology, 24 (1), 41 70.

[5] Bandura, A. (2006). Guide for constructing self efficacy scales. Self - efficacy beliefs of adolescents, 5 (1), 307 - 337.

[6] Baum, J. R, \& Wally, S. (2003). Strategic decision speed and firm performance. Strategic Management Journal, 24 (11), 1107 - 1129.

[7] Bentler, P. M., \& Bonett, D. G. (1980). Significance tests and goodness of fit in the analysis of covariance structures. Psychological bulletin, 88 (3), 588.

[8] Blume, B. D., Ford, J. K., Baldwin, T. T., \& Huang, J. L. (2010). Transfer of training: A meta - analytic review. Journal of management, 36 (4), 1065 - 1105.

[9] Boone, C., Brabander, B., \& Witteloostuijn, A. (1996). CEO locus of control and small firm performance: An integrative framework and empirical test. Journal of Management studies, 33 (5), 667 - 700.

[10] Brinkerhoff, R. O., \& Montesino, M. U. (1995). Partnerships for training transfer: Lessons from a corporate study. Human Resource Development Quarterly, 6, 263-274

[11] Brown, L. R. (2001). State of the World, 2001: A Worldwatch Institute Report on Progress Toward a Sustainable Society. WW Norton \& Company.

[12] Burke, T. R. (2007). U. S. Patent No.7, 254, 573. Washington, DC: U. S. Patent and Trademark Office.

[13] Collins, C. J., \& Clark, K. D. (2003). Strategic human resource practices, top management team social networks, and firm performance: The role of human resource practices in creating organizational competitive advantage. Academy of management Journal, 46 (6), 740 - 751.

[14] Easterly, W., \& Levine, R. (2001). What have we learned from a decade of empirical research on growth? It's Not Factor Accumulation: Stylized Facts and Growth Models. the world bank economic review, 15 (2), 177 - 219.

[15] Facteau, J. D., Dobbins, G. H., Russell, J. E. A., Ladd, R. T., \& Kudisch, J. D. (1995). The influence of general perceptions of the training environment on pretraining motivation and perceived training transfer. Journal of Management, 21, 1 - 25.

[16] Federation, T. A., Organisations, E., Board, G., Register, A. E., Asean, T., Register, E., ... Countries, A. (1998). REGISTRATION PROCEDURE TO THE ASEAN ENGINEERS REGISTER (AER) Preamble Aims of the AER, 64-66.

[17] Ford, J. K., Smith, E. M., Weissbein, D. A., Gully, S. M. and Salas, E. (1998), "'Relationships of goal orientation, metacognitive activity, and practice strategies with learning outcomes and transfer', Journal of Applied Psychology, 83 (2), 218 - 33.

[18] Hair, J. F, Anderson, R., Tatham, R., \& Black, W. (1998). ( $5^{\text {th }}$ ed.). Multivariate Data Analysis, Prentice Hall International: London.

[19] Hair, J. F., Celsi, M. W., Ortinau, D. J., \& Bush, R. P. (2008). Essentials of marketing research. McGraw Hill/Higher Education.

[20] Hoàng, T. \& Chu N. M. N. (2007), Thống Kê Úng Dụng trong Kinh tế - Xã hội, Nhà Xuất Bản Thống Kê.
[21] Jenkins, R. (2004). Vietnam in the global economy: trade, employment and poverty. Journal of International Development, 16 (1), 13 - 28.

[22] Jöreskog, K. G., \& Sörbom, D. (1989). LISREL 7 user's reference guide. Scientific Software.

[23] Kakkar, A. K., Cimminiello, C., Goldhaber, S. Z., Parakh, R., Wang, C., \& Bergmann, J. F. (2011). Low - molecular - weight heparin and mortality in acutely ill medical patients. New England Journal of Medicine, 365 (26), 2463 - 2472.

[24] Martocchio, J. J., \& Judge, T. A. (1997). Relationship between conscientiousness and learning in employee training: Mediating influences of self - deception and self - efficacy. Journal of Applied Psychology, 82, 764-773.

[25] McIver, J., \& Carmines, E. G. (1981). Unidimensional scaling (Vol.24). Sage.

[26] Mohammed, S., Mathieu, J. E., \&Bart'Bartlett, A. L. (2002). Technical-administrative task performance, leadership task performance, and contextual performance: considering the influence of team-and task-related composition variables. Journal of Organizational Behavior, 23 (7), 795 - 814.

[27] Land, R. E. (2012). Engineering technologists are engineers. Journal of Engineering Technology, 29 (1), $32-39$.

[28] Lân, D. Đ. (2012). Tiêu chuẩn về kỹ năng nghề - Yếu tố cơ bản để cái cách giáo dục kỹ thuật và dạy nghề trong bối cánh hội nhập Asean. (Professional skills criteria: Essentials for renovation in technology education and vocational training in ASEAN integration)

[29] Levine, R., \& Renelt, D. (1992). A sensitivity analysis of cross - country growth regressions. The American economic review, 942 - 963.

[30] Lucas Jr, R. E. (1988). On the mechanics of economic development. Journal of monetary economics, 22 (1), $3-42$.

[31] Marshall, B., Mills, R., \& Olsen, D. (2008). The role of end - user training in technology acceptance. Review of Business Information Systems, 12 (2), 1 - 8.

[32] Naeem, S., Duffy, J. E., \& Zavaleta, E. (2012). The functions of biological diversity in an age of extinction. Science, 336 (6087), 1401 - 1406.

[33] Nguyen, N. Q. \& Nguyen V. D. (2004), Quản trị nhân lực (Tái bản 2): NXB ĐHKTQD. (Human Resource Management. National Economic University Press.)

[34] Nguyen, D. T., \& Nguyen, T. M. T. (2009). Scientific research in business. Chicago.

[35] Nguyen, D. T., \& Nguyen, T. M. T. (2009). Scientific research in business. Chicago.

[36] Noe, R. A., \& Schmitt, N. (1986). The influence of trainee attitudes on training effectiveness: Test of a model. Personnel psychology, 39 (3), 497 - 523.

[37] Nunnally, J. (1978). C. (1978). Psychometric theory, 2.

[38] Nunnally, J. C., \& Bernstein, I. H. (1994). Psychological theory. New York, NY: MacGraw Hill.

[39] Papademetriou, D. G., Sugiyarto, G., Mendoza, D. R., \& Salant, B. (2016). Achieving Skill Mobility in the ASEAN Economic Community: Challenges, Opportunities, and Policy Implications. Asian Development Bank. 
[40] Phillips, J. J. (2009). Accountability in human resource management. Routledge.

[41] Pincus, J. (2009). Vietnam: Sustaining growth in difficult times. ASEAN Economic Bulletin, 26 (1), 11 24.

[42] Quinones, M. A. (1995). Pretraining context effects: Training assignment as feedback. Journal of applied psychology, 80 (2), 226.

[43] Romer, P. M. (1990). Endogenous technological change. Journal of political Economy, 98 (5, Part 2), S71 - S102.

[44] Rouiller, J. Z., \& Goldstein, I. L. (1993). The relationship between organizational transfer climate and positive transfer of training. Human resource development quarterly, 4 (4), 377 - 390.

[45] Saks, A. M., \& Belcourt, M. (2006). An investigation of training activities and transfer of training in organizations. Human resource management, 45 (4), $629-648$.

[46] Schmidt, U. (2004). Vietnam's integration into the global economy. Achievements and challenges. Asia Europe Journal, 2 (1), 63 - 83.

[47] Scullion, H., Collings, D. G., \& Gunnigle, P. (2007). International human resource management in the $21 \mathrm{st}$ century: Emerging themes and contemporary debates. Human Resource management journal, 17 (4), 309 319.

[48] Sew, G. S. (2000). Apec engineer register, challenges and the way forward to promote mobility of engineering services. APEC Engineer Report.

[49] Shen, J., \& Darby, R. (2006). Training and management development in Chinese multinational enterprises. Employee Relations, 28 (4), 342 - 362.

[50] Seiler, S., Lent, B., Pinkowska, M., \& Pinazza, M. (2012). An integrated model of factors influencing project managers' motivation-Findings from a Swiss Survey. International Journal of Project Management, 30 (1), 60 - 72.

[51] Steiger, J. H. (1990). Structural model evaluation and modification: An interval estimation approach. Multivariate behavioral research, 25 (2), 173 - 180.

[52] Stevens, C. K., \& Gist, M. E. (1997). Effects of self-efficacy and goal-orientation training on negotiation skill maintenance: what are the mechanisms?. Personnel Psychology, 50 (4), 955 978.

[53] Tannenbaum, S. I., Mathieu, J. E., Salas, E. and Cannon - Bowers, J. A. (1991), 'Meeting trainees' expectations: the influence of training fulfillment on the development of commitment, self - efficacy, and motivation', Journal of Applied Psychology, 76 (6), 759 - 769.

[54] Tesluk, P. E., Farr, J. L., Mathieu, J. E., \& Vance, R. J. (1995). Generalization of employee involvement training to the job setting: Individual and situational effects. Personnel Psychology, 48 (3), 607 - 632.

[55] Tracey, J. B., Hinkin, T. R., Tannenbaum, S., \& Mathieu, J. E. (2001). The influence of individual characteristics and the work environment on varying levels of training outcomes. Human resource development quarterly, 12 (1), 5.

[56] Tracey, J. B., \& Tews, M. J. (2005). Construct validity of a general training climate scale. Organizational
Research Methods, 8 (4), 353 - 374.

[57] Tziner, A., Fisher, M., Senior, T., \& Weisberg, J. (2007). Effects of trainee characteristics on training effectiveness. International Journal of Selection and Assessment, 15 (2), 167 - 174.

[58] United Nations. (2009). Economic and Social Council Science, technology and engineering for innovation and capacity - building in education and research.

[59] Xiao, J. (1996). The relationship between organizational factors and the transfer of training in the electronics industry in Shenzhen, China. Human Resource Development Quarterly, 7 (1), 55 - 73.

\section{Websites:}

[60] http: //www.oecd. org/

[61] https: //www.engineersireland ie/groups/divisions/civil/publications. aspx

[62] https: //en. wikipedia org/wiki/Certified_Engineering_Technologist

[63] https: //baomoi. com/ky - su - viet - nam - co - nang luc - tot/c/19607728. epi

[64] https: //baomoi. com/suc - hut - nganh - cong - nghe - o - to/c/23040024. epi

[65] http: //century. custhelp. com/app/answers/detail/a_id/220/ /the - difference between - engineering - and - engineering technology $\% 3 \mathrm{~F}$

[66] http: //digitalcommons. ilr. cornell. edu/cgi/viewcontent. cgi? article $=1498 \&$ context=intl

[67] http: //en. nhandan. com. vn/opinions/item/5387502 asean - economic - community - \%E2\%80\%93 opportunities - and - challenges. html

[68] http: //ijecm. co. uk/wp content/uploads/2015/05/3538. pdf

[69] https: //oxfordbusinessgroup. com/analysis/neighbourly - relations - readying integration - asean - economic - community

[70] http: //tapchitaichinh. vn/nghien - cuu - trao doi/nghien - cuu - dieu - tra/thuc - trang - nguon - nhan - luc - cong - nghe - cao - o - viet - nam - 95308. html

[71] http: //vietnamlawmagazine. vn/aec - 2025 - fresh opportunities - and - challenges - for - vietnam - 5511. html

[72] https: //vnexpress. net/tin - tuc/khoa - hoc/viet - nam thieu - nhan - luc - khoa - hoc - cong - nghe - co - ky nang - cao - 2928213. html

[73] http: //vovworld. vn/en - US/current - affairs/vietnam aims - at - developing - highquality - human resources - 331400. vov

[74] https: //www.aseanbriefing com/news/2016/05/13/asean - labor - mobility. html

[75] http: //www.economicmodeling. com/2014/09/12/in demand - and - aging - a - look - at - engineers - and engineering - technicians - in - the - workforce/

[76] https: //www.nap. edu/read/23402/chapter/6

[77] https: //www.septeni - holdings. co. jp/en/csr/activity/hr. html

[78] http: //www.worldwatch. org/increase - labor - force can - be - engine - development - 0

[79] http: //xedoisong. vn/thi - truong/hang - nghin - ky - su - o - to - viet - nam - dang - lam - viec - trai - nghe 5608. html 
[80] http: //xettuyennghe. tuoitre. vn/tin/ky - nang - nghe nghiep/20170607/cong - nghe - ky - thuat - o - to nghe - dang - hot/24. html 